\title{
TU/e EmonOWEN

\section{Wear and friction of Y-TZP spheres reciprocating against various Sialon plates}

\section{Citation for published version (APA):}

van den Berg, P. H. J., With, de, G., Dortmans, L. J. M. G., Kokmeijer, E., \& Cao, G. Z. (1993). Wear and friction of Y-TZP spheres reciprocating against various Sialon plates. Journal of Materials Science, 28(12), 3187-3196. https://doi.org/10.1007/BF00354235

DOI:

10.1007/BF00354235

Document status and date:

Published: 01/01/1993

\section{Document Version:}

Publisher's PDF, also known as Version of Record (includes final page, issue and volume numbers)

\section{Please check the document version of this publication:}

- A submitted manuscript is the version of the article upon submission and before peer-review. There can be important differences between the submitted version and the official published version of record. People interested in the research are advised to contact the author for the final version of the publication, or visit the $\mathrm{DOI}$ to the publisher's website.

- The final author version and the galley proof are versions of the publication after peer review.

- The final published version features the final layout of the paper including the volume, issue and page numbers.

Link to publication

\section{General rights}

Copyright and moral rights for the publications made accessible in the public portal are retained by the authors and/or other copyright owners and it is a condition of accessing publications that users recognise and abide by the legal requirements associated with these rights.

- Users may download and print one copy of any publication from the public portal for the purpose of private study or research.

- You may not further distribute the material or use it for any profit-making activity or commercial gain

- You may freely distribute the URL identifying the publication in the public portal.

If the publication is distributed under the terms of Article 25fa of the Dutch Copyright Act, indicated by the "Taverne" license above, please follow below link for the End User Agreement:

www.tue.nl/taverne

Take down policy

If you believe that this document breaches copyright please contact us at:

openaccess@tue.nl

providing details and we will investigate your claim. 


\title{
Wear and friction of Y-TZP spheres reciprocating against various sialon plates
}

\author{
P. H. J. VAN DEN BERG*, G. DE WITH ${ }^{\ddagger a}$, L. DORTMANS*, E. KOKMEIJER* \\ G. - Z. CAO*ף \\ * Centre for Technical Ceramics, PO Box 595, Eindhoven, The Netherlands \\ $\ddagger$ Philips Research Laboratories, PO Box 80000, $5600 \mathrm{JA}$, Eindhoven, The Netherlands ${ }^{a}$
}

The friction and wear characteristics of various $Y-T Z P$-sialon sliding systems were examined. These systems consisted of a $Y$-TZP sphere reciprocating against various sialon plates. The sialons differed in phase content and composition. They range from $\alpha$-sialons to $\beta$-sialons and include $\alpha-\beta$ composites. The length of the wear tracks was $10 \mathrm{~mm}$, the loads used were 2 and $8 \mathrm{~N}$, the frequencies 1,4 and $8 \mathrm{~Hz}$ and the humidity was controlled by flushing with dry nitrogen. The tests were continued for 8,24 and $72 \mathrm{~h}$ at room temperature. The total vertical displacement and the friction coefficient were measured continuously and sampled. Various additional measurements were performed after each test and the worn surfaces were observed microscopically. It was concluded that the $\alpha-\beta$ composites show less wear than the $\alpha$-and $\beta$-sialons. It was also concluded that the amount of wear increases approximately linearly with load and increases significantly more than linearly with frequency. A wear mechanism was derived incorporating the measured data and the observations.

\section{Introduction}

Many structural ceramics are regarded as materials suitable for wear-resistant applications. However, the complexity of a wear system has made it difficult to present common laws and it is practically impossible to give reliable predictions for a wear system which has not been tested before.

There has already been a substantial amount of interest in the literature in the wear behaviour of ceramics (e.g. [1-9]). Some of this literature is about common principles that are likely to play a significant role (e.g. $[1,2]$ ) or about round-robin tests (e.g. $[3,4]$ ). In some cases large amounts of experimental data are given from many wear systems, together with explanatory considerations (e.g. [5-9]). In some other cases, the literature is about a rigidly defined wear system clearly corresponding to a certain application (e.g. [10-12]). Much more research remains to be done before reasonable predictions can be given for a specific wear system.

For this study, wear systems of an yttrium-doped tetragonal zirconia polycrystal (Y-TZP) sphere sliding reciprocatively against various sialon plates were investigated. Sialons are an interesting kind of structural ceramic [13-17], often mentioned in the literature as a wear-resistant material [18-22] and in some cases specifically as a material suitable for cutting tools $[21,22]$. Zirconias are well-known materials fabricated in several varieties. One of these varieties is Y-TZP [23-27]. Some of the properties of the material have been described (e.g. [23, 24]), the subject of superplasticity has been treated (e.g. [25]) and degradation, important when the material is heated above $100^{\circ} \mathrm{C}$, has been discussed (e.g. $[26,27]$ ). The material has often been investigated as a wear-resistant material (e.g. [28-30]).

In this study two test series were performed. The first series was done to investigate the influence of variations in the phase content or the composition of the sialon on the friction and wear characteristics of the system. The second series, performed on a single type of $\alpha$-sialon, was done to study the influence of load and velocity and to examine the reproducibility of the measurements. Earlier tests on various $\beta$-sialons, as described elsewhere [31], were performed under slightly different conditions to the first series of tests for the $\alpha$-sialons. Some additional measurements were therefore performed on one $\beta$-sialon to compare the tribological properties of $\alpha$ - and $\beta$-sialons under the same conditions.

The friction coefficient and the total vertical displacement were continuously measured during the tests and sampled at certain time intervals. This continuous measuring of the vertical displacement is not recommended in the ASTM standard [32] because of the effects of debris and film formation, but it does give relevant information about the system during the test. Both film formation and the role of debris can be incorporated in a model describing the wear behaviour.

\footnotetext{
${ }^{\S}$ Present address: KEMA department CMO, PO Box 9035, 6800 ET Arnhem, The Netherlands.

Tresent address: University of Twente, Laboratory of Inorganic Chemistry, PO Box 217, 7500 AE Enschede, The Netherlands.

also affiliated with the Centre for Technical Ceramics.
} 
After each test various geometrical measurements were performed and the worn surfaces were visually examined with optical microscopy $(\mathrm{OM})$ and scanning electron microscopy (SEM). Some surfaces were examined with energy-dispersive analysis of X-rays (EDAX). The data and observations were used to derive a wear mechanism.

\section{Experimental procedure}

The pin material used was in all tests a commercially available Y-TZP sphere with a radius of $2 \mathrm{~mm}$ and a polished surface. In Table I the properties of Y-TZP, measured on a plate of the same material from the same supplier, are given. These values are assumed to be comparable to the properties of the spheres. The sialons were fabricated at the Centre for Technical Ceramics. A summary of some of their properties is given in Table 1. Most tests were performed on $\alpha$ sialons with different compositions (codes A1, A2, A3 and $\mathrm{A} 4$ ) and on composites (codes A5, A6 and A7). Additional tests were done with a $\beta$-sialon (B5). Details of the processing and characteristics of these sialons are given elsewhere $[15,16]$. The sialons were ground to a surface roughness, $R_{\mathrm{a}}$, of $0.25 \mu \mathrm{m}$.

The wear tests were performed on a pin-on-plate tribometer (Central Technical Workshop, Eindhoven University of Technology). In this set-up, a spherical Y-TZP pin reciprocates with a sinusoidal velocity on the flat sialon plate. The track length for the tests was chosen as $10 \mathrm{~mm}$ with pin frequencies, $f$, of 1,4 and $8 \mathrm{~Hz}$ corresponding to maximum velocities of respectively $0.02,0.08$ and $0.16 \mathrm{~m} \mathrm{~s}^{-1}$. Normal loads, $P$, of 2 and $8 \mathrm{~N}$ were used. The duration was varied from 8 to $72 \mathrm{~h}$. The experiments were performed in a flow of dry nitrogen at room temperature. This gives an approximately constant environment of less then $1 \%$ relative humidity.

The total vertical displacement of the pin during sliding was measured by an extensometer (Sangamo DG1). The frictional force was measured by a force transducer. The displacement and frictional force were simultaneously sampled under external triggering control with a computerized data acquisition system. After each external trigger pulse 2560 data points were taken in five series of 512 points, both for the vertical displacement and for the force signal, with a certain sampling frequency. For a pin frequency of $1 \mathrm{~Hz}$, a sampling frequency of $50 \mathrm{~Hz}$ was used and for frequencies of 4 and $8 \mathrm{~Hz}$, the sampling frequency was $100 \mathrm{~Hz}$. The vertical displacement values were averaged. The auto-power spectrum of the force signal was calculated by fast Fourier transformation (FFT) [33]. This FFT was performed on the five time records of 512 points whose individual power spectra were subsequently averaged. The total energy was approximated by integrating the first, third and fifth order harmonics of the auto-power spectrum. Higher order harmonics can be neglected. The friction coefficient $f_{\mathrm{c}}$ was calculated from these values according to

$$
f_{\mathrm{c}}=\frac{\left(Q_{1}+Q_{3}+Q_{5}\right)^{1 / 2}}{P}
$$

where $Q_{i}$ is the power of the $i$ th harmonic and $P$ the normal load.

Various additional geometrical measurements were performed. The weight loss of the pin was measured when possible and the track width on the plate was measured with the device mounted on a Leitz microhardness tester. The decrease in diameter of the worn Y-TZP sphere was measured with an extensometer (Heidenhain MT30, VT103) and profiles of some wear tracks on the plate were measured with a Talysurf 5 (Rank-Taylor-Hobson, Leicester). The worn surfaces were observed with OM and SEM. Some surfaces of worn spheres were examined with EDAX.

Two test series were performed as described in Table II. The first series was performed to determine whether there are significant differences in the tribological properties of the various sialons and composites. Various $\beta$-sialons were tested at a load of $4 \mathrm{~N}$ and at a frequency $1 \mathrm{~Hz}$ in an earlier study [31],

TABLE I Characteristics of the materials used.

\begin{tabular}{|c|c|c|c|c|c|c|c|c|c|}
\hline \multirow[t]{2}{*}{ Material code } & \multirow[t]{2}{*}{ Y-TZP } & \multicolumn{8}{|c|}{ Sialon code $\mathrm{e}^{\mathrm{x}}$} \\
\hline & & A1 & $\mathrm{A} 2$ & $\mathrm{~A} 3$ & A4 & A5 & A6 & $\mathrm{A} 7$ & B6 \\
\hline$\alpha / \beta$ content & - & 1 & 1 & 1 & 1 & 0.75 & 0.40 & 0.35 & 0 \\
\hline$\rho\left(\mathrm{kg} \mathrm{m}^{-3}\right)$ & 5.86 & 3.33 & 3.29 & 3.28 & 3.27 & 3.23 & 3.22 & 3.23 & 3.13 \\
\hline$E(\mathrm{GPa})$ & 208 & 317 & 327 & 322 & 316 & 332 & 324 & 313 & 230 \\
\hline v & 0.32 & 0.28 & 0.29 & 0.29 & 0.28 & 0.30 & 0.30 & 0.29 & 0.30 \\
\hline$d(\mu \mathrm{m})^{\mathrm{b}}$ & 1.15 & & $4 / 0$ & $4 / 0$ & $4 / 0$ & $3 / 14$ & & & $0 / 30$ \\
\hline$\sigma_{3 \mathrm{pb}}(\mathrm{GPa})^{\mathrm{c}}$ & 966 & & & & & & & & \\
\hline$\sigma_{\mathrm{bi}}(\mathrm{GPa})^{\mathrm{c}}$ & & 517 & 519 & 57.0 & 553 & 734 & 680 & 598 & 480 \\
\hline$K_{\mathrm{ic}}\left(\mathrm{MPa} \mathrm{m}^{1 / 2}\right)^{\mathrm{d}}$ & 7.9 & 5.7 & 5.6 & 5.4 & 5.3 & 6.0 & 5.8 & 5.7 & 2.8 \\
\hline$H_{\mathrm{v}}(2 N)(G P a)$ & 13.0 & & & & & & & & 14.5 \\
\hline$H_{\mathrm{V}}(0.5 \mathrm{~N})(\mathrm{GPa})$ & & 21.0 & 19.6 & 19.4 & 18.9 & 17.2 & 16.8 & 14.5 & \\
\hline
\end{tabular}

${ }^{a}$ Most data for the sialons are taken from [15] and [16]. The codes Al-A7 are used for the $\alpha$-sialons and composites. The code B6 is used for a $\beta$-sialon.

${ }^{b}$ Given for sialons as the average diameter of the $\alpha$ grains and the maximum length of the $\beta$ grains. For Y-TZP the average grain diameter is given.

${ }^{\mathrm{c}}$ Measured in a three-point bend test, $\sigma_{3 \mathrm{pb}}$, or in a biaxial test, $\sigma_{\mathrm{bi}}$.

${ }^{d}$ For Y:TZP and B6 sialon, values were measured in a single-edge notched beam test, while values for $\alpha$-sialons were measured with the indentation method. 
whereas in the present study the various $\alpha$-sialons and the composites were tested at a load of $8 \mathrm{~N}$ and at frequencies of 1 and $4 \mathrm{~Hz}$. The second series was performed on one $\alpha$-sialon (A2), chosen for no particular reason, to investigate the reproducibility of the measurements, to study the influence of load and frequency and to derive a wear mechanism for this system. This $\alpha$-sialon was tested at normal loads of 2 and $8 \mathrm{~N}$, at frequencies of 1,4 and $8 \mathrm{~Hz}$ and at times of 8,24 and $72 \mathrm{~h}$ as shown in Table 2 . Four additional tests were done on a $\beta$-sialon, (B6) under similar conditions as the tests performed on the $\alpha$-sialon, to compare the wear behaviour of the $\beta$-sialon and the $\alpha$-sialon.

\section{Results}

In the following we present first some considerations about the geometry of the contact surface between a worn sphere and plate. This is done because the interpretation of the geometrical measurements is not straightforward if both pin and plate show significant amounts of wear. The contact surface between the plate and the pin has a complex geometry. Therefore two models (illustrated in Fig. 1) were used to approximate the shape of the contact surface from the measured geometrical data. A listing of the symbols used is included in the text of Fig. 1.

According to model $\mathrm{A}$, the surface of the sphere, which is in contact with the plate, will develop into a flatter shape which can be seen as part of a new sphere with a larger radius $r^{\prime}$. This $r^{\prime}$ can be calculated from $y, r$ and $a$, and can be used to calculate the wear volumes of the sphere, using the area $A_{2}$, and plate, using the $A_{1}$. In model $\mathrm{B}$, the sphere is flat at the bottom and keeps the original radius at the side which has also been in contact with the plate. This represents an upper boundary with a minimum amount of wear for the sphere. The radius of the bottom circle, $b$, can again be calculated from $r, y$ and $a$ and the wear volumes of the pin and plate can be calculated using respectively areas $A_{2}$ and $A_{1}$. Model $\mathrm{A}$ results in a maximum amount of wear for the sphere and a minimum amount for the plate, while model B results in the opposite. Both models assume that the profile of the sphere in the direction of the wear track is the same as the profile at right-angles to the wear track.

The width of the wear track, $2 a$, can be measured directly. The decrease in diameter of the sphere, $y$, can

TABLE II Measurement scheme in which the first series was performed to examine the tribological properties of various sialons and the second series to examine the influence of $P, f$ and $t$

\begin{tabular}{llll}
\hline Material & $P(\mathrm{~N})$ & $f(\mathrm{~Hz})$ & $t(\mathrm{~h})$ \\
\hline $\begin{array}{l}\text { First series } \\
\text { A1-A7 }\end{array}$ & 8 & 1 & 72 \\
A1-A7 & 8 & 4 & 24 \\
B1-B5 & 4 & 1 & 50 \\
Second series & & & \\
A2 & 2,8 & $1,4,8$ & $8,24,72$ \\
B6 & 2,8 & 1,4 & 24,72 \\
\hline
\end{tabular}

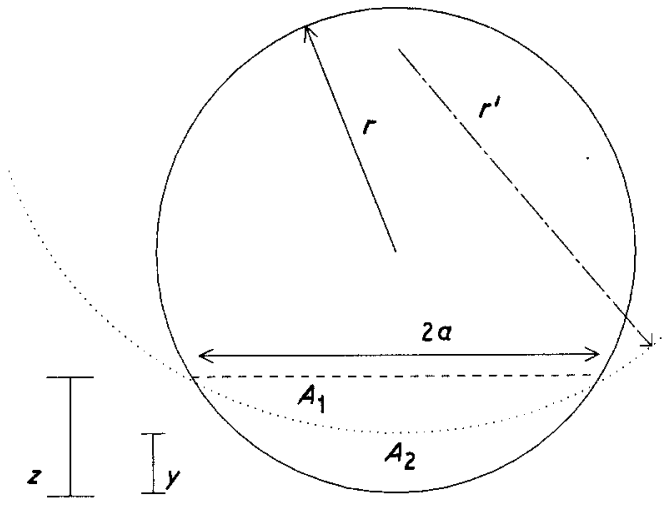

(a)

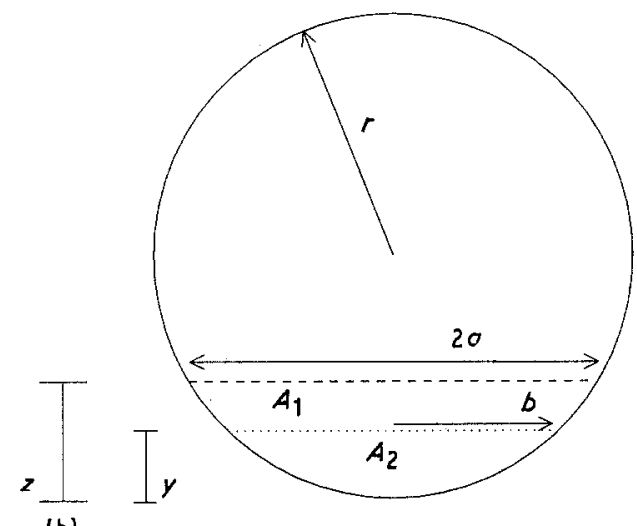

(b)

Figure 1 Two models to describe the shape of the contact surface between a sphere and a plate if both materials show wear (for explanation, see text). The initial radius of the sphere is given by $r$, $a$ is the radius as measured from the track width, $y$ is the decrease in diameter of the sphere as measured, $z$ is the maximum vertical wear-depth as derived from $a$ and $r, A_{1}$ is the worn area of the plate in cross-section, $A_{2}$ is the worn area of the sphere in cross section, $r^{\prime}$ is the new sphere radius used in model $\mathrm{A}$, and $b$ is the radius of the circle which can be imagined on the assumption of a completely flat pin as used in model $\mathbf{B}$.

be measured only if enough material has been removed during the wear process. The weight measurements of the pin give the true volume losses which can be used to determine whether model $\mathrm{A}$ or model $\mathrm{B}$ is more appropriate. A factor $\Delta$, defined as

$$
\Delta=\frac{W_{\mathrm{wt}}-W_{\mathrm{B}}}{W_{\mathrm{A}}-W_{\mathrm{B}}}
$$

will be used henceforth. The term $W_{w t}$ is the volumetric amount of wear as calculated from the measured weight loss; $W_{\mathrm{A}}$ and $W_{\mathbf{B}}$ are the theoretical wear volumes based on respectively model $A$ and model $B$. $A$ value of zero for $\Delta$ means wear according to model $B$ and a value of unity indicates wear according to model A.

The value of $a$ can also be used to calculate $z$, which is the summation of the decrease in diameter of the sphere and the depth of material removed from the plate. The value of $z$ can be compared with $h$, although they are not supposed to be equal.

In Fig. $2 a$ and $b$ two examples are given of profiles of wear tracks. The radius of curvature and the depth of the wear track can be measured from these graphs. The shapes of the profiles clearly resemble the two models A and B from Fig. 1. 

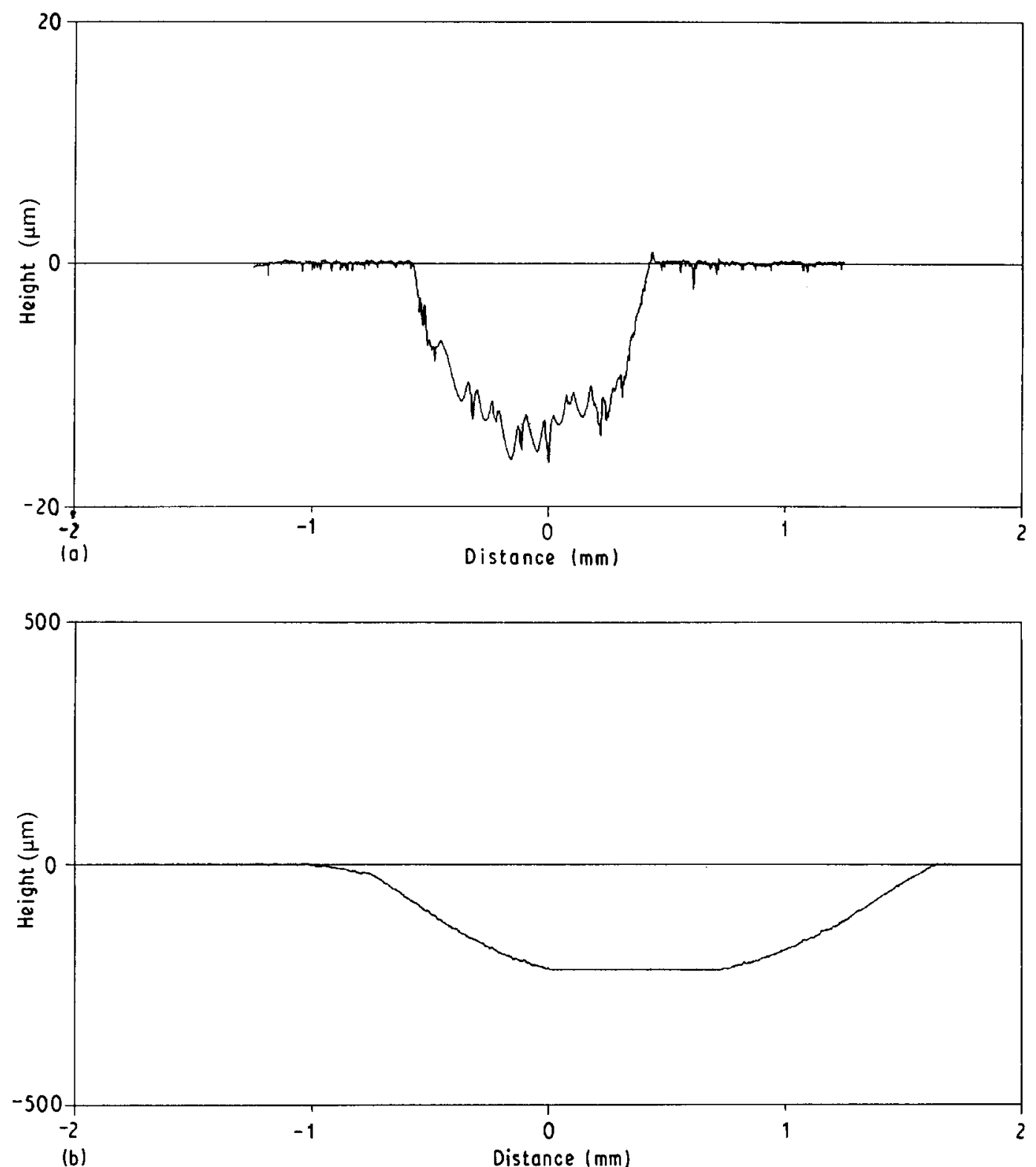

Figure 2 (a) Profile of wear track caused by a test at $2 \mathrm{~N}$ and $4 \mathrm{~Hz}$ for $72 \mathrm{~h}$ on sample A2. This profile shows a clear correspondence to model A from Fig. 1. (b) Profile of wear track caused by a test at $2 \mathrm{~N}$ and $8 \mathrm{~Hz}$ for $24 \mathrm{~h}$ on sample A2. This profile shows a clear correspondence to model $\mathrm{B}$ from Fig. 1. The scales in (a) and (b) are entirely different.

The results of the first series of tests performed on various $\beta$-sialons are presented elsewhere [31]. These tests show no differences in tribological properties between the various $\beta$-sialons.

The results of the first series of tests on the $\alpha$-sialons and the $\alpha-\beta$ composites are given in Table III. The friction coefficients $f_{\mathrm{c}}(0)$ listed first in Table III are the values at the beginning of the test and the values $f_{\mathrm{c}}(t)$ are the steady-state friction coefficients. The tests performed at a frequency of $1 \mathrm{~Hz}$ resulted in hardly any wear. Therefore no $y$ values are given. The only geometric variables which could be measured reliably were $a$ and the continuously measured vertical displacement, $h$. Some of the tests performed at $4 \mathrm{~Hz} \mathrm{did}$ show enough wear to determine all the other variables. The results of this analysis are given in Table IV.

The average values given in Tables III and IV show a small, but consistent, difference in wear between the $\alpha$-sialons and the composites. The values for $a, z$ and $h$ in Table III show the difference for the whole
Y-TZP-sialon system while Table IV shows the separate values for the sphere and the plate. It is shown in Table IV that the wear of the Y-TZP spheres depends more on the sialon type than the wear of the sialon plates themselves. The steady-state friction coefficient $f_{\mathfrak{c}}(t)$ is less for tests with a composite than with tests with a pure $\alpha$-sialon.

The value for $\Delta$ in Table IV depends on the sialon type, pure $\alpha$ or a composite, and thus on the amount of wear. Less wear, as for the composites, gives a low value for $\Delta$ and thus a preference for model B.

The results from the second series of wear tests, performed on sialons $\mathrm{A} 2$ and $\mathrm{B} 6$ under various conditions, are summarized in Table V. In Figs 3 and 4 the reproducibility of the vertical displacement measurements is illustrated. The majority of the tests showed the same good reproducibility. Not only the total amount of vertical displacement, but also the shape of the graphs and the occurrence of incidental events (Fig. $4 \mathrm{a}$ and b) are reproduced. 
TABLE III Results of the first series of wear tests (all performed at a load of $8 \mathrm{~N}$ )

\begin{tabular}{lllllllll}
\hline Sialon code & $a(\mathrm{~mm})$ & $y(\mathrm{~mm})$ & $z(\mathrm{~mm})$ & $h(\mathrm{~mm})$ & $r^{\prime}(\mathrm{mm})$ & $b(\mathrm{~mm})$ & $f_{\mathrm{c}}(0)$ & $f_{\mathrm{c}}(t)$ \\
\hline
\end{tabular}

Measurements at $1 \mathrm{~Hz}$ for $72 \mathrm{~h}$ at $8 \mathrm{~N}$

(i) $\alpha$-sialons

$\begin{array}{ll}\text { A1 } & 0.40 \\ \text { A1d } & 0.32 \\ \text { A2 } & 0.61 \\ \text { A3 } & 0.58 \\ \text { A3d } & \\ \text { A4 } & 0.55 \\ \text { Average } & 0.49\end{array}$

$\begin{array}{lll}0.40 & & \\ 0.32 & 0.040 & \\ 0.61 & 0.026 & 0.063 \\ 0.58 & 0.100 & 0.078 \\ & 0.086 & 0.090 \\ 0.55 & & 0.045 \\ 0.49 & 0.077 & 0.066 \\ & 0.066 & \end{array}$

(ii) Composites

\begin{tabular}{|c|c|c|c|c|c|}
\hline A5 & 0.50 & 0.064 & 0.038 & & \\
\hline $\mathrm{A} 5 \mathrm{~d}$ & 0.35 & 0.030 & & 0.45 & 0.34 \\
\hline A6 & & & 0.100 & 0.30 & 0.47 \\
\hline$A 6 \mathrm{~d}$ & 0.42 & 0.044 & 0.047 & 0.48 & 0.44 \\
\hline A7 & 0.40 & 0.040 & 0.041 & 0.31 & 0.29 \\
\hline Average & 0.42 & 0.045 & & & \\
\hline
\end{tabular}

Average

0.42

0.045

Measurements at $4 \mathrm{~Hz}$ for $24 \mathrm{~h}$ at $8 \mathrm{~N}$

(i) $\alpha$-sialons

$\begin{array}{lrrrrrrrr}\text { A1 } & 1.70 & 0.43 & 0.95 & >0.80 & 3.01 & 1.24 & 0.25 & 0.90 \\ \text { Ald } & & & & 0.26 & & & 0.39 & 0.60 \\ \text { A2 } & 1.47 & 0.38 & 0.64 & >0.50 & 4.16 & 1.17 & 0.37 & 0.74 \\ \text { A3 } & 1.53 & 0.36 & 0.71 & >0.50 & 3.47 & 1.14 & 0.15 & 0.67 \\ \text { A3d } & & & & 0.24 & & & 0.24 & 0.52 \\ \text { A4 } & 1.58 & 0.41 & 0.78 & 0.62 & 3.60 & 1.21 & 0.13 & 0.70\end{array}$

$\begin{array}{lll}\text { Average } & 1.57 & 0.77\end{array}$

(ii) Composites

$\begin{array}{lllllllll}\text { A5 } & 1.36 & 0.35 & 0.53 & >0.30 & 5.13 & 1.13 & 0.14 & 0.50 \\ \text { A6 } & & & & & & & 0.12 & 0.50 \\ \text { A6d } & 1.40 & 0.28 & 0.57 & 0.45 & 3.51 & 1.02 & 0.31 & 0.53 \\ \text { A7 } & 1.53 & 0.31 & 0.72 & 0.52 & 3.08 & 1.06 & 0.16 & 0.67\end{array}$

Average

1.43

0.61

Measurements at $1 \mathrm{~Hz}$ for $50 \mathrm{~h}$ at $4 \mathrm{~N}$ (only $\beta$-sialons ${ }^{\mathrm{b}}$ )

B1

B2

B2d

B3

B3d

B4

B5

$\begin{array}{ll}0.027 & 0.52 \\ 0.018 & 0.44 \\ 0.014 & 0.40 \\ 0.010 & 0.37 \\ 0.025 & 0.42 \\ 0.025 & 0.48 \\ 0.012 & 0.39\end{array}$

a "d" stands for a duplicate measurement.

${ }^{\mathrm{b}}$ The codes B1-B5 stand for various $\beta$-sialons which were processed along different routes. The density varied from $3.08 \mathrm{to} 3.21 \mathrm{~g} \mathrm{~cm}^{-3}$, $\mathrm{H}_{\mathrm{V}}(2.0 \mathrm{~N})$ from 14.5 to $17.3 \mathrm{GPa}, E$ from 218 to $249 \mathrm{GPa}$, $v$ from 0.285 to $0.299, K_{\mathrm{IC}}$ from 2.51 to $3.63 \mathrm{MPa} \mathrm{m}^{1 / 2}$ and $\sigma_{\mathrm{bi}}$ from 383 to $467 \mathrm{MPa}$.
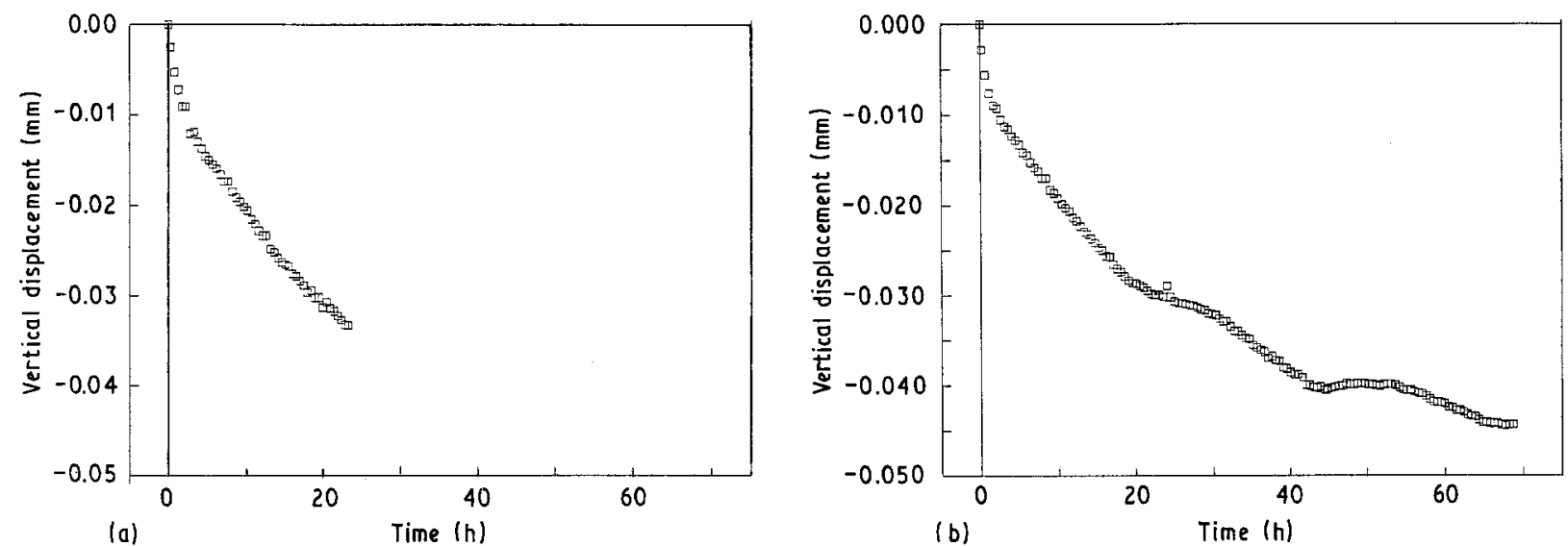

Figure 3 (a) Example of a vertical displacement graph. The test was performed at $2 \mathrm{~N}$ and $4 \mathrm{~Hz}$ for about $24 \mathrm{~h}$ on sample A2. (b) Graph of a test of about $70 \mathrm{~h}$ performed under the same conditions as in the test given in (a). The first $24 \mathrm{~h}$ in this graph compare well with (a). 
TA B LE IV Calculation of wear volumes $(W)$ according to models $\mathrm{A}\left(W_{\mathrm{A}}\right)$ and $\mathrm{B}\left(W_{\mathrm{B}}\right)$ for sphere and plate for tests performed at a frequency of $4 \mathrm{~Hz}$ at a load of $8 \mathrm{~N}$

\begin{tabular}{|c|c|c|c|c|c|c|c|}
\hline $\begin{array}{l}\text { Sialon } \\
\text { code }^{a}\end{array}$ & $\begin{array}{l}W_{\mathrm{A}}\left(\mathrm{mm}^{3}\right) \\
\text { spheré }\end{array}$ & $\begin{array}{l}W_{\mathrm{B}}\left(\mathrm{mm}^{3}\right) \\
\text { sphere }\end{array}$ & $\begin{array}{l}W_{w w}\left(m m^{3}\right) \\
\text { weight }\end{array}$ & $\Delta^{\mathrm{b}}$ & $\begin{array}{l}W_{\mathrm{A}}\left(\mathrm{mm}^{3}\right) \\
\text { plate }\end{array}$ & $\begin{array}{l}W_{\mathrm{B}}\left(\mathrm{mm}^{3}\right) \\
\text { plate }\end{array}$ & $\begin{array}{l}W_{\text {calc }}\left(\mathrm{mm}^{3}\right) \\
\text { plate }\end{array}$ \\
\hline \multicolumn{8}{|c|}{$\alpha$-sialons } \\
\hline Al & 2.33 & 1.07 & 1.45 & 0.30 & 12.15 & 15.73 & 14.65 \\
\hline A2 & 1.41 & 0.83 & 1.15 & 0.55 & 5.30 & 7.14 & 6.13 \\
\hline A3 & 1.49 & 0.76 & 0.85 & 0.14 & 7.35 & 9.64 & 9.32 \\
\hline A4 & 1.83 & 0.98 & 1.43 & 0.53 & 7.79 & 10.34 & 8.99 \\
\hline Average & & & 1.22 & & & & 9.77 \\
\hline \multicolumn{8}{|c|}{ Composites } \\
\hline A5 & 1.09 & 0.72 & 0.71 & $\sim 0$ & 3.34 & 4.59 & 4.59 \\
\hline A6d & 0.93 & 0.46 & 0.56 & 0.21 & 5.43 & 7.07 & 6.73 \\
\hline A7 & 1.29 & 0.56 & 0.79 & 0.31 & 8.50 & 10.86 & 10.13 \\
\hline Average & & & 0.69 & & & & 7.15 \\
\hline
\end{tabular}

${ }^{a}$ Code according to Table I, d stands for duplicate.

${ }^{b}$ Calculated wear volumes for the spheres are compared with wear volumes derived from weight losses $\left(W_{\mathrm{wt}}\right)$ and the relative importance of the models is expressed by $\Delta$ (see text). With this $\Delta$ an estimation for the wear volume of the plate can be calculated. This calculated value is given in the last column as $W_{\text {salc }}$.

TABLE V Results from the second series of wear tests

\begin{tabular}{|c|c|c|c|c|c|c|c|c|c|}
\hline Sialon code & $P(\mathrm{~N})$ & $f(\mathrm{~Hz})$ & $t(\mathrm{~h})$ & $a(\mathrm{~mm})$ & $y(\mathrm{~mm})$ & $h(\mathrm{~mm})$ & $z(\mathrm{~mm})$ & $f_{c}(t)$ & $b(\mathrm{~mm})$ \\
\hline $\mathrm{A} 2$ & 2 & 1 & $\begin{array}{r}8 \\
24 \\
72\end{array}$ & $\begin{array}{l}0.17 \\
0.21 \\
0.21\end{array}$ & & $\begin{array}{l}0.003 \\
0.007 \\
0.013\end{array}$ & $\begin{array}{l}0.007 \\
0.011 \\
0.012\end{array}$ & $\begin{array}{l}0.45 \\
0.44 \\
0.37\end{array}$ & \\
\hline $\mathrm{A} 2$ & 2 & 4 & $\begin{array}{l}24 \\
72\end{array}$ & $\begin{array}{l}0.39 \\
0.51\end{array}$ & & $\begin{array}{l}0.034 \\
0.045\end{array}$ & $\begin{array}{l}0.038 \\
0.065\end{array}$ & $\begin{array}{l}0.54 \\
0.46\end{array}$ & $\begin{array}{l}0.18 \\
0.24\end{array}$ \\
\hline $\mathrm{A} 2$ & 2 & 8 & $\begin{array}{r}8 \\
24\end{array}$ & $\begin{array}{l}1.11 \\
1.33\end{array}$ & $\begin{array}{l}0.21 \\
0.28\end{array}$ & $\begin{array}{l}0.180 \\
0.280\end{array}$ & $\begin{array}{l}0.334 \\
0.507\end{array}$ & $\begin{array}{l}0.80 \\
0.80\end{array}$ & $\begin{array}{l}0.89 \\
0.91\end{array}$ \\
\hline A2 & $\varepsilon$ & 1 & $\begin{array}{r}8 \\
24 \\
72\end{array}$ & $\begin{array}{l}0.27 \\
0.34 \\
0.61\end{array}$ & & $\begin{array}{l}0.013 \\
0.022 \\
0.080\end{array}$ & $\begin{array}{l}0.019 \\
0.028 \\
0.096\end{array}$ & $\begin{array}{l}0.39 \\
0.44 \\
0.50\end{array}$ & \\
\hline $\mathrm{A} 2$ & 8 & 4 & $\begin{array}{r}8 \\
24\end{array}$ & $\begin{array}{l}0.32 \\
1.47\end{array}$ & 0.38 & $\begin{array}{l}0.033 \\
0.600\end{array}$ & $\begin{array}{l}0.026 \\
0.645\end{array}$ & $\begin{array}{l}0.27 \\
0.65\end{array}$ & 1.17 \\
\hline $\mathrm{A} 2$ & 8 & 8 & 4 & 1.11 & 0.23 & 0.280 & 0.333 & 0.47 & 0.94 \\
\hline B6 & 2 & 1 & $\begin{array}{l}24 \\
72\end{array}$ & $\begin{array}{l}0.19 \\
0.23\end{array}$ & & $\begin{array}{l}0.007 \\
0.015\end{array}$ & $\begin{array}{l}0.009 \\
0.014\end{array}$ & $\begin{array}{l}0.39 \\
0.40\end{array}$ & \\
\hline B6 & 2 & 4 & 72 & 0.34 & & 0.080 & 0.075 & 0.47 & \\
\hline B6 & 8 & 1 & 72 & 0.54 & & 0.028 & 0.029 & 0.37 & \\
\hline
\end{tabular}
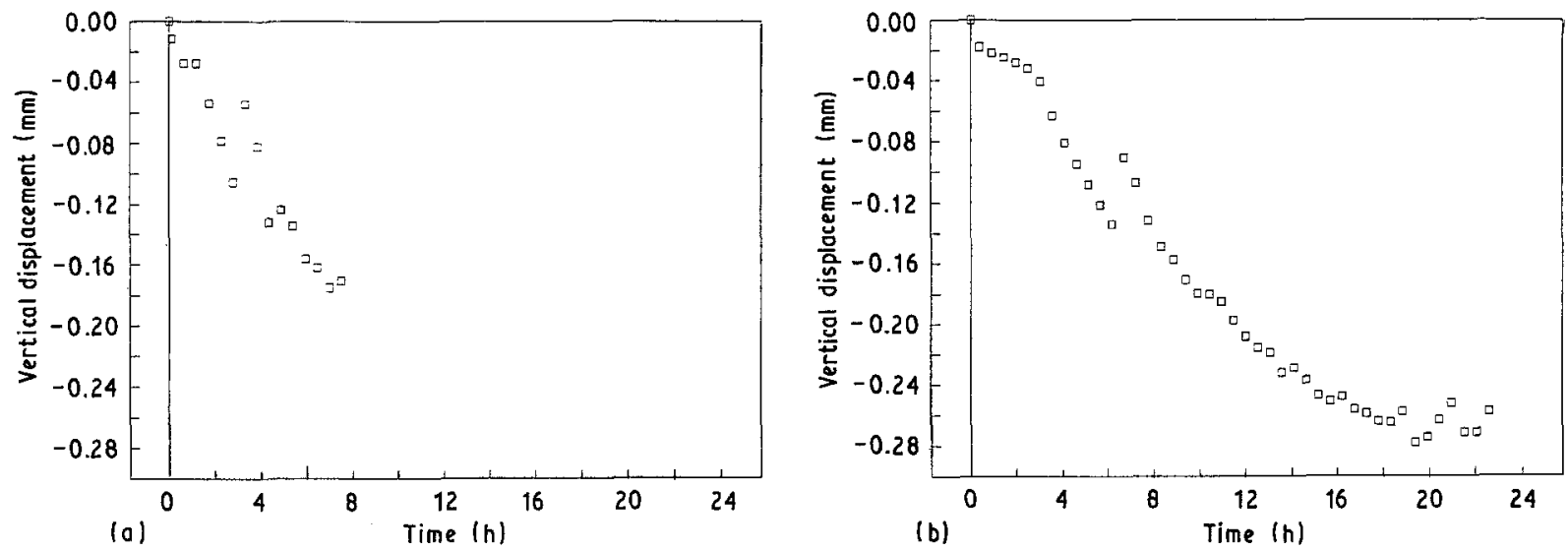

Figure 4 (a) Example of a vertical displacement graph of a test performed at $2 \mathrm{~N}$ and $8 \mathrm{~Hz}$ for about $8 \mathrm{~h}$ on sample A2. (b) Graph of a test of about $24 \mathrm{~h}$ performed under the same conditions as in the test given in (a). Not only is the amount of vertical displacement comparable with (a), but also the occurrence of an event as in (a) after $3 \mathrm{~h}$ and in (b) after $5 \mathrm{~h}$. 
The relevant interdependencies of vertical displacement, friction, load and frequency are presented in Figs 5 and 6 . The preferable method to obtain comparable data is to present, the data at a certain total sliding distance. The results for the friction coefficients are given in Fig. 5a and b. The tests performed with a load of $2 \mathrm{~N}$ show an increase in friction coefficient with increasing frequency. The friction coefficients at a load of $8 \mathrm{~N}$ are less than the friction coefficients at a load of $2 \mathrm{~N}$ at frequencies of 4 and $8 \mathrm{~Hz}$.

Data for the ratio vertical displacement/load after certain sliding distances versus frequency are given in Fig. 6. The data are directly taken from the vertical displacement graphs from which time and frequency are used to calculate the sliding distance. The dependence of vertical displacement on load is approximately linear as shown by the clusters of points. A representation of vertical displacement-load as a function of frequency after a certain sliding distance thus presents a clear picture of the wear-enhancing influence of increasing frequency.

The results of the four additional tests on the $\beta$ sialon are similar to the results of the tests on the $\alpha$-sialon as shown in Fig. 6a and b.

In Figs 7 to 10 pictures from worn surfaces are shown. The characteristics of these surfaces depend on the test conditions and not on the sialon type. The surface of the plate as shown in Fig. 7 is typical for tests at low load and low frequency. A surface with "holes", elongated particles and an occasional straight dark band is visible. After tests under intermediate conditions for load and frequency, a wear surface as shown in Fig. 8 is usually observed with straight dark bands alternating with bands of a "polished" surface. At high load and frequency a surface is observed as in Fig. 9. The surface is covered with a dark layer without structure. These observations are also reported elsewhere [31]. The notion of dark bands or a dark layer on surfaces observed with $O M$ is an indication of areas which reflect less light than accompanying bright areas. A heavily distorted, ploughed area next to a relatively flat area will appear as a dark area. Samples observed with SEM show parts with adhered and distorted material next to areas with material which resembles the unworn part of the plate. In Fig. 10 the surface of a Y-TZP sphere as observed with SEM is shown with various dark parts fixed on or into the Y-TZP. These parts were identified with EDAX as sialon. These observations and the test data were used to derive a wear mechanism for this system.

\section{Discussion}

The slight difference in wear resistance for the sphere and the plate between tests with sialon composites and the $\alpha$-sialons can possibly be related to the higher fracture toughness and the lower hardness of the com-
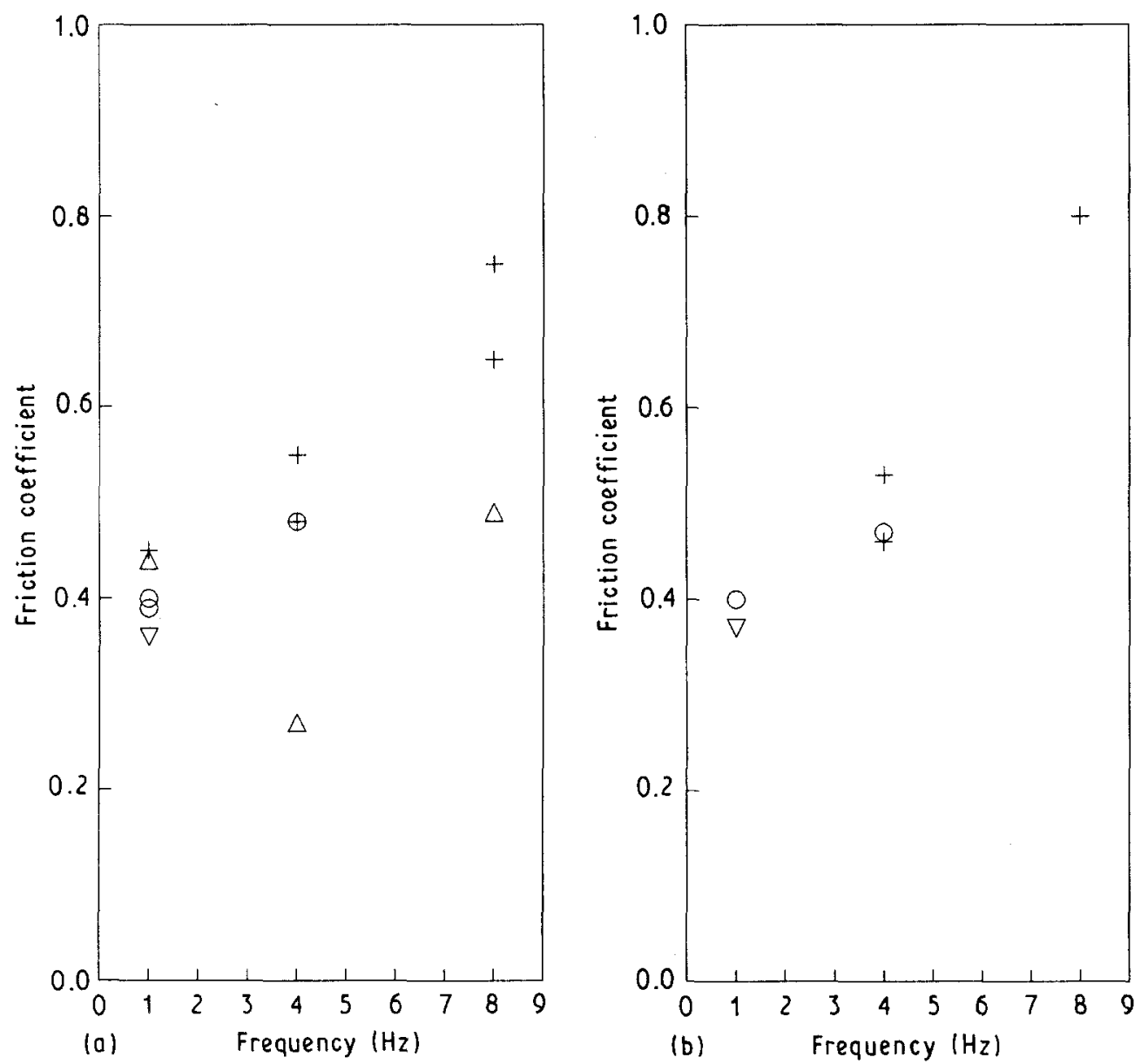

Figure 5 (a) Friction coefficient $f_{\mathrm{c}}(t)$ as a function of frequency after $1.73 \mathrm{~km}$ sliding distance; (b) as in (a), but now after $5.18 \mathrm{~km}$ sliding distance. ( +) A2, $P=2 \mathrm{~N} ;(\triangle) \mathrm{A} 2, P=8 \mathrm{~N} ;(\bigcirc) \mathrm{B} 6, P=2 \mathrm{~N} ;(\nabla) \mathrm{B} 6, P=8 \mathrm{~N}$. 

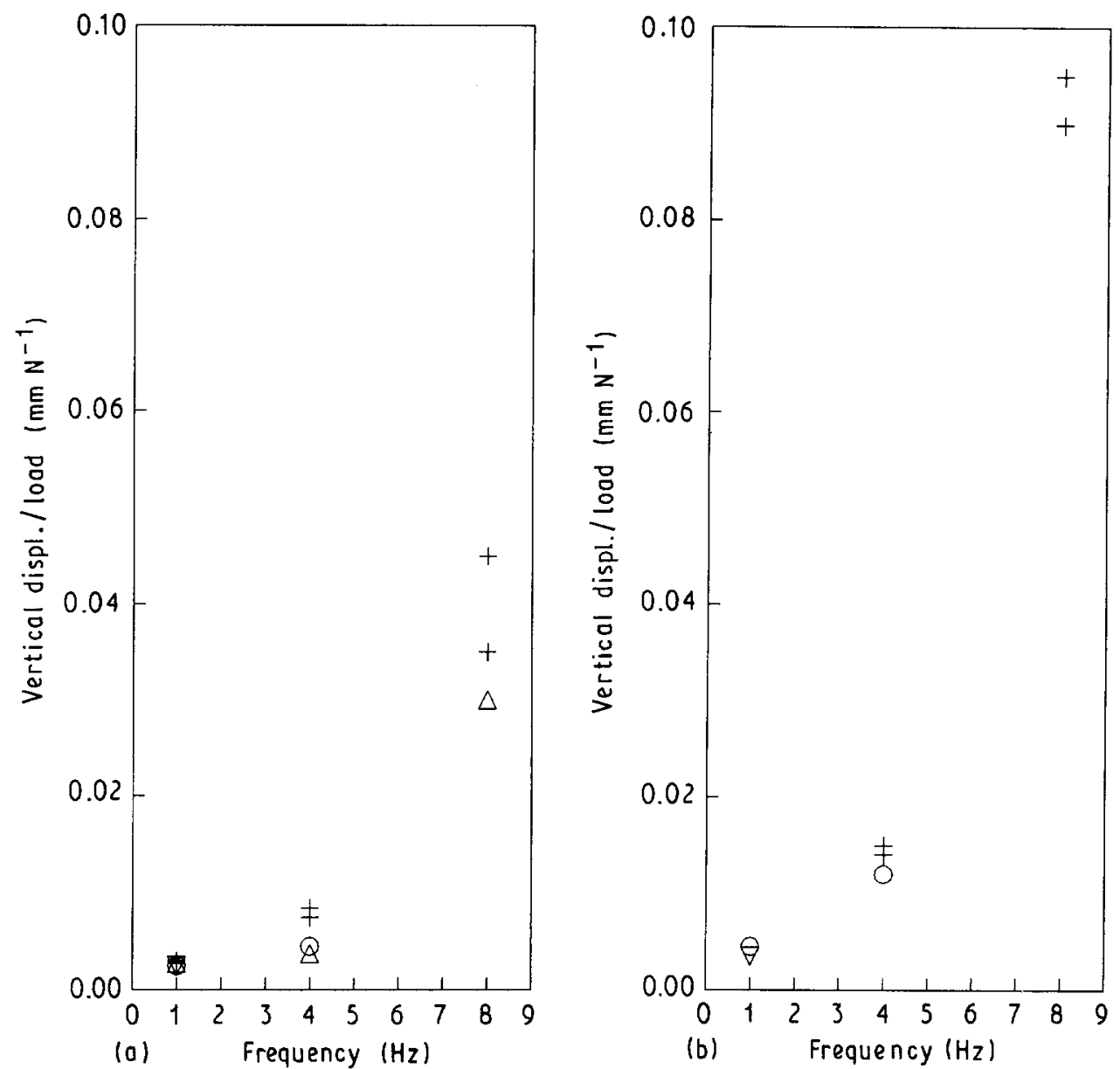

Figure 6 (a) Total vertical displacement divided by load in after $1.73 \mathrm{~km}$ sliding distance as a function of frequency; (b) as in (a) but now after $5.18 \mathrm{~km}$ sliding distance. $(+) \mathrm{A} 2, P=2 \mathrm{~N} ;(\triangle) \mathrm{A} 2, P=8 \mathrm{~N} ;(\bigcirc) \mathrm{B} 6, P=2 \mathrm{~N} ;(\nabla) \mathrm{B} 6, P=8 \mathrm{~N}$.

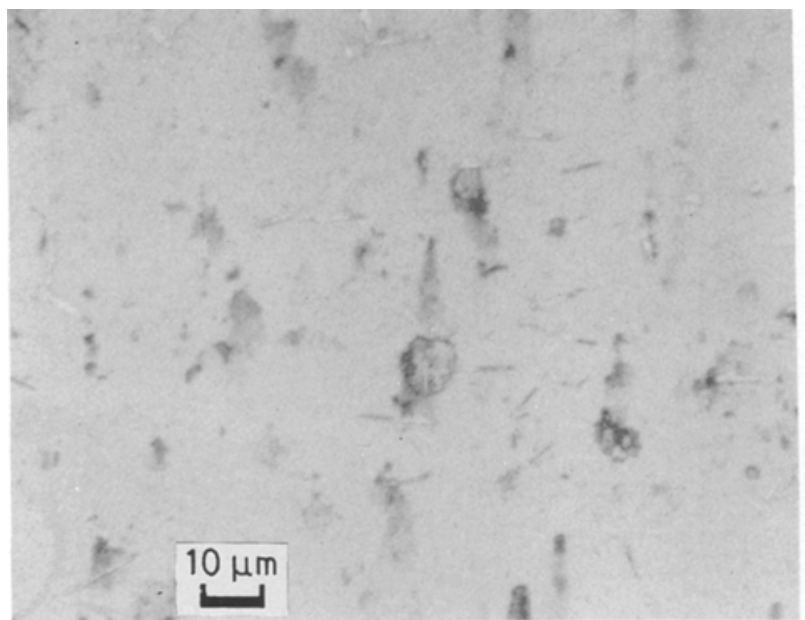

Figure 7 Example of a wear surface of an $\alpha$-sialon, A8, after a test at $8 \mathrm{~N}$ and $1 \mathrm{~Hz}$ for $72 \mathrm{~h}$. This picture was taken with normal light microscopy at a magnification of $630 \times$. The surface is characteristic for wear by plastic deformation under mild conditions.

posites, which are shown in Table I. This is logical but not supported by additional arguments.

The geometrical changes during a wear test in the contact between the sphere and the plate are not entirely clear, but there is some correspondence between the models and the experimental data. In the initial stages of wear, the surface of the sphere is flattened to a sphere with a larger radius than the

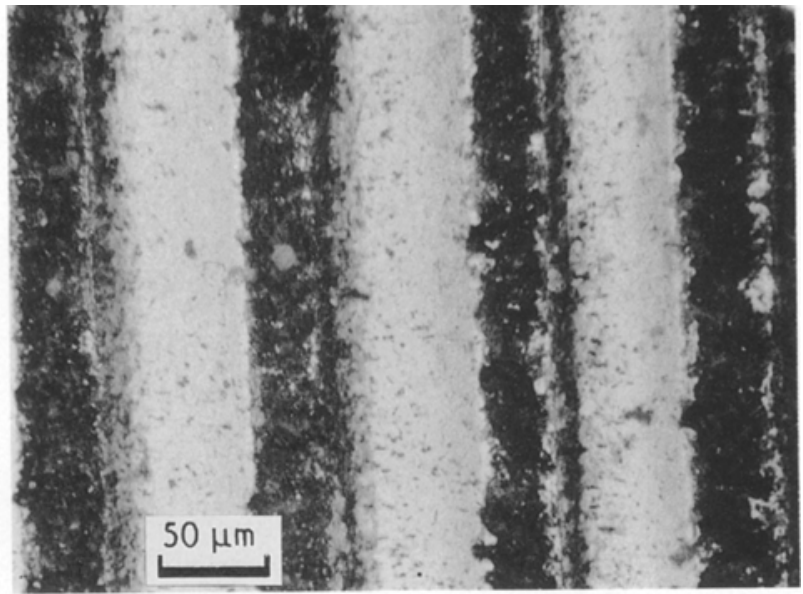

Figure 8 Example of a wear surface of $\alpha$-sialon A2 after a test at $2 \mathrm{~N}$ and $4 \mathrm{~Hz}$ for $72 \mathrm{~h}$. This picture was taken with normal light microscopy at a magnification of $255 \times$. The surface is characteristic for wear by both plastic deformation and abrasion under intermediate conditions.

original radius as shown in Fig. 2a because the plate as well as the sphere is worn. During continued wear, the area of contact will increase because an increased area of contact reduces local pressures. This means that model $B$ is now more appropriate since the area of contact is larger for model B than for model A. Another relevant concept is the local pressure at the angles between the flat part and the curved part of the 


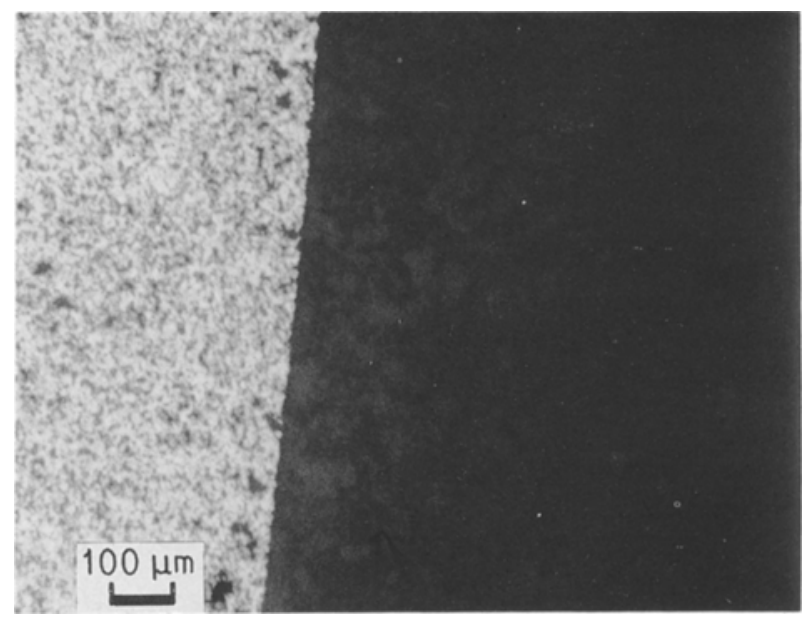

Figure 9 Example of a wear surface of $\alpha$-sialon $\mathrm{A} 9$ after a test at $8 \mathrm{~N}$ and $4 \mathrm{~Hz}$ for $24 \mathrm{~h}$. This picture was taken with normal light microscopy at a magnification of $69 \times$. The worn surface is the dark part of the figure and the bright part is the original surface. This wear surface is characteristic for wear by abrasion under severe conditions.

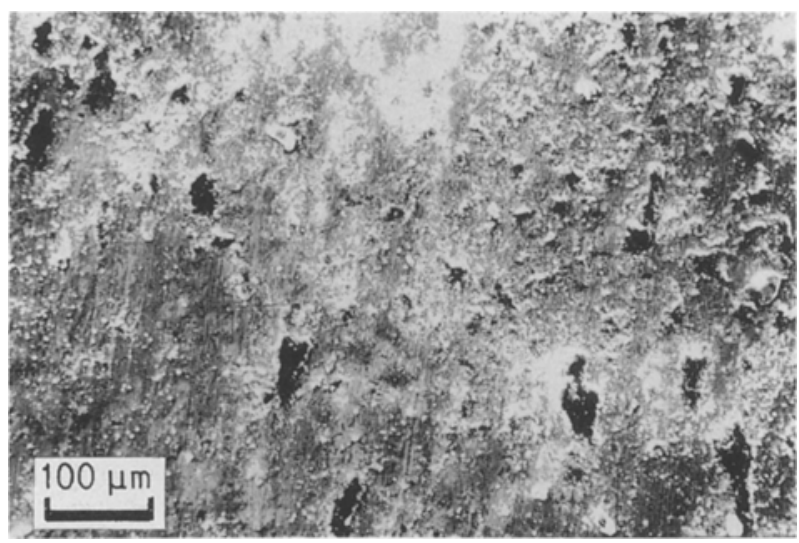

Figure 10 Example of a worn Y-TZP surface after a test against composite $\mathrm{A} 9$ at $8 \mathrm{~N}$ and $4 \mathrm{~Hz}$ for $24 \mathrm{~h}$. The dark pits are identified as sialon fragments. This picture was taken with scanning electron microscopy at a magnification of $120 \times$.

contact surface. If model B is followed, this angle will become sharper with increasing wear and the local pressure at this angle will increase. If the amount of wear is further increased, this corner will be flattened and this will result in a wear surface which can be described as a sphere according to model A. Table IV, which gives the results after tests performed under constant, rather severe conditions, shows the increasing importance of model A with increasing wear.

The reproducibility as shown in Figs 3 and 4 is an indication of the reliability of the tests. These tests were performed on one $\alpha$-sialon. The large scatter between the data in Table III, more common for a wear test, is ascribed to the use of different materials. Small differences between material properties which appear to be irrelevant for the usually measured characteristics could well cause large differences in wear behaviour.

The friction data given in Fig. 5 indicate a load and frequency dependence of friction. An increase in friction with increasing frequency could be explained by
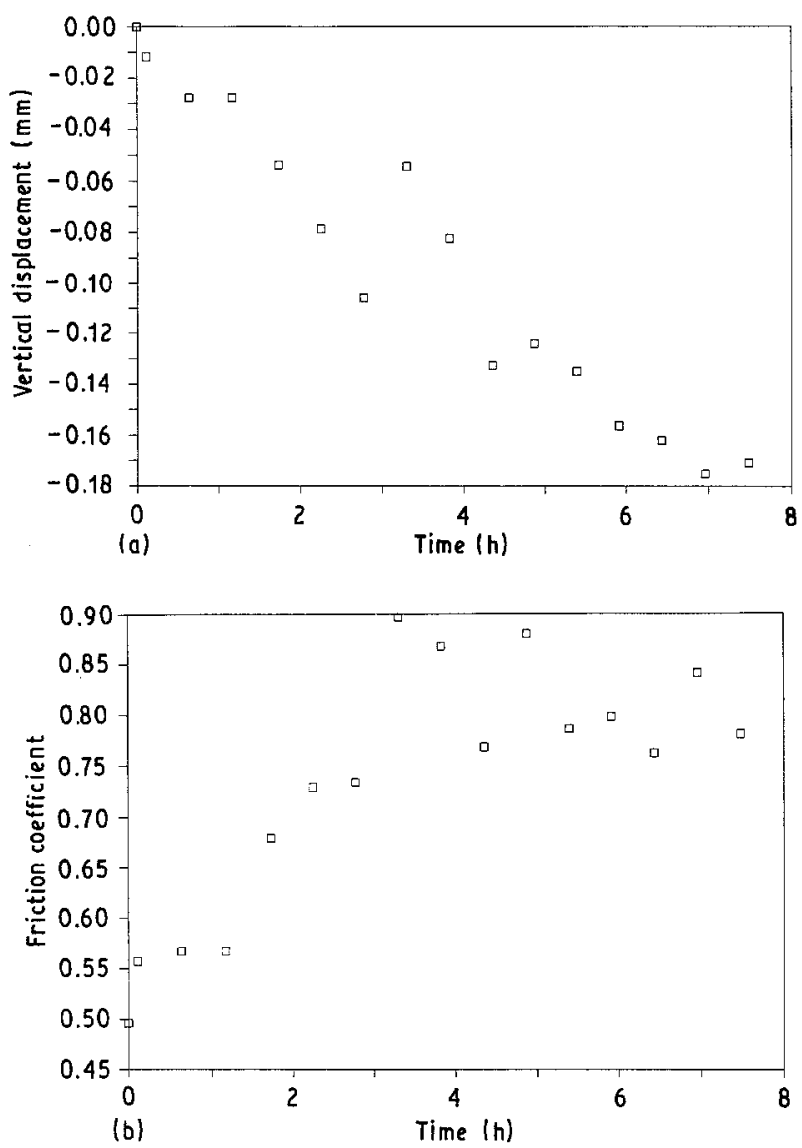

Figure 11 (a) The same vertical displacement graph as in Fig. 4a, to illustrate the correspondence in events between the vertical displacement and the friction; (b) Friction coefficient graph corresponding to (a). The incidental event after $3 \mathrm{~h}$ is present in both graphs.

the increasing importance of abrasion at higher frequencies. The lower friction at a load of $8 \mathrm{~N}$ relative to the friction at a load of $2 \mathrm{~N}$ is restricted to frequencies of 4 and $8 \mathrm{~Hz}$ and is not understood.

The relations between the total vertical displacement, frequency and load are illustrated in Fig. 6. The clustering of points is an indication of an approximately linear relation between load and vertical displacement, since values of vertical displacement/load are plotted along the vertical axis. The severe increase in the total amount of wear with increasing frequency corresponds to the relative importance of abrasion, which will be discussed later.

There is some correspondence between the graphs of vertical displacement and the friction graphs. Points in the friction graph which are clearly higher or lower than the average friction usually correspond to discontinuities in the graph of the vertical displacement, as shown by an example given in Fig. 11 .

These considerations, the observations from worn surfaces and the various graphs are now used to derive a model for the wear mechanism. Basically, wear in the Y-TZP-sialon system is possible because of plastic deformation of both materials. The difference in hardness between Y-TZP and the sialons is not large enough to prevent wear of either one of the materials. Severe wear by abrasion is possible due to the following process. Adhesion is concentrated at the turning points on the plate. At these turning points, sialon 
fragments break loose from the plate and are incidentally attached to the Y-TZP sphere as shown by EDAX. This can be caused either by adhesion or because the sialon fragment is indented into the sphere. These sialon fragments will cause abrasion of the plate in a straight line, resulting in a dark band on the plate. When such a fragment is attached to the sphere, there can be an upward movement of the sphere which is observed in the vertical displacement graph. During abrasion of the fragment this upward movement can continue due to the increase in debris. Occasionally a larger piece of sialon part can cause an incidental large upward movement corresponding to an incidental change in friction. A higher frequency will enhance these processes. Many sialon fragments attached to the sphere will cause a film of abraded debris. Frequency is thus the main variable which determines the contribution of abrasion to the total amount of wear. More experimental work could be done on comparable systems to verify these considerations.

\section{Summarizing conclusions}

1. Tests performed in the wear system on the same sialon type are reproducible. The scatter in results for measurements on different materials is large.

2. Wear tests with a composite results in less wear of both the Y-TZP sphere and the plate compared to the tests with a pure $\alpha$ - or $\beta$-sialon.

3. The total vertical displacement is approximately linear 'with load.

4. The total vertical displacement increases severely with increasing frequency at loads of 2 and $8 \mathrm{~N}$. The friction coefficient increases with increasing frequency at a load of $2 \mathrm{~N}$.

5. Plastic deformation of both materials causes wear under mild conditions.

6. Adhesion and the development of debris in the contact area giving abrasion are assumed to be the cause of severe wear of both materials.

\section{Acknowledgements}

This work was partly supported by the Commission for the Innovative Research Programme Technical Ceramics (IOP-TK) of the Ministry of Economic Affairs in the Netherlands (IOP-TK research grant 90A211). The authors would like to thank W. de Maeyer for his work on the data acquisition system, B. George for carrying out part of the experimental work and Dr A. Broese van Groenou for many useful discussions.

\section{References}

1. H. KITSUNAI, K. KATO, K. HOKKIRIGAWA and H. INOUE, Wear 135 (1990) 237.

2. S. M. HSU, Y. S. WANG and R. G. MUNRO, ibid. 134 (1989) 1.

3. E. A. ALMOND and M. G. GEE, ibid. 120 (1987) 101.

4. H. CZICHOS, S. BECKER and J. LEXOW, ibid. 135 (1989) 171.

5. J. DENAPE and J. LAMON, J. Mater. Sci. 25 (1990) 3592.

6. O. O. A JAYI and K. C. LUDEMA, Wear 140 (1990) 191.

7. S. JAHANMIR and T. E. FISCHER, STLE Trans. 31 (1988) 32.

8. M. G. GEE, C. S. MATHARU, E. A. ALMOND and T. S. EYRE, Wear 138 (1990) 169.

9. S. SASAKI, ibid. 134 (1989) 185.

10. I. BIRK BY, P. HARRISON and R. STEVENS, J. Eur. Ceram. Soc. 5 (1989) 37.

11 R. W. RICE and C. C. W U, Ceram. Eng. Sci. Proc. 6 (1985) 1012.

12. H, H. STURHAHN, W. DAWIHL and G. THAMERUS, Ber. Deutsch. Keram. Ges. 52 (1975) 84.

13. K. BREDER, T. ANDERSON and K. SCHÖLIN, J. Amer. Ceram. Soc. 73 (1990) 2128.

14. A. K. MUKHOPADHYAY, S. K. DATTA and D. CHAKR A BORTY, Ceram. Int. 17 (1991) 121.

15. E. KOKMEIJER, G. de WITH and R. METSELAAR, J. Eur. Ceram. Soc. 8 (1991) 71.

16. G.-Z. CAO, "Preparation and Characterization of $\alpha^{\prime}$-Sialon Ceramics," PhD thesis, Eindhoven University of Technology (1991).

17. G.-Z. CAO and R. METSELAAR, Chem. Mater. 3 (1991) 242

18. Z. P. WANG and C. RUIZ, Wear 140 (1990) 107.

19. Y. NAKAMURA and S. HIRAYAMA, ibid. 137 (1990) 91.

20. C. YIN-QIAN, D. XIANG-DONG, W. FU-XING, C. QI-GONG and Z. ZHANG-XIAO, ibid. 137 (1990) 175.

21. J. AUCOTE and S. R. FOSTER, Mater. Sci. Techn. 2 (1986) 700 .

22. S. K. BHATTACHARYA, A. JAWAID, M. H. LEWIS and J. WALLBANK, Metals Techn. 10 (1983) 482.

23. T. MASAKI, J. Amer, Ceram. Soc. 69 (1986) 638.

24. J. LANKFORD, R. A. PAGE and L. RABENBERG, $J$. Mater. Sci. 23 (1988) 4144.

25. I-W. CHEN and L. A. XUE, J. Amer. Ceram. Soc. 73 (1990) 2885.

26. T. SATO and M. SHIMADA, ibid. 68 (1985) 365.

27. M. YOSHIMURA, T. NOMA, K. KAWABATA and S. SOMIYA, J. Mater. Sci. Lett. 6 (1987) 465.

28. G. W. STACHIOWIAK and G. B. STACHIOWIAK, Wear 132 (1989) 151.

29. I. BIRK BY, P. HARRISON and R. STEVENS, J. Eur. Ceram. Soc. 5 (1989) 37.

30. T. E. FISCHER, M. P. ANDERSON, S. JAHANMIR and R. SALHER, Wear 124 (1988) 133.

31. E. KOKMEIJER, "Sintering Behaviour and Properties of $\beta^{\prime}-\mathrm{Si}_{3} \mathrm{Al}_{3} \mathrm{O}_{3} \mathrm{~N}_{5}$ Ceramics", $\mathrm{PhD}$ thesis, Eindhoven University of Technology (1990).

32. ASTM G-99, "Standard test method for wear testing with a pin-on-disk apparatus" (June, 1990).

33. D. E. NEWLAND, "Random Vibrations and Spectral Analysis" (Longman, London, 1975).

Received 29 January

and accepted 17 November 1992 